\title{
Effects of Clove Oil Anaesthesia on Rainbow Trout (Oncorhynchus mykiss)
}

\author{
J. VELÍŠEK ${ }^{1}$, Z. SVOBODOVÁ 2,3 , V. PIAČKOVÁ ${ }^{2}$ \\ ${ }^{1}$ Faculty of Agriculture, University of South Bohemia České Budějovice, Czech Republic \\ ${ }^{2}$ Research Institute of Fish Culture and Hydrobiology Vodnany, University of South Bohemia \\ České Budějovice, Czech Republic \\ ${ }^{3}$ University of Veterinary and Pharmaceutical Science Brno, Czech Republic
}

Received August 23,2004

Accepted March 3, 2005

\begin{abstract}
Velíšek J., Z. Svobodová, V. Piačková: Effects of Clove Oil Anaesthesia on Rainbow Trout (Oncorhynchus mykiss). Acta Vet. Brno 2005, 74: 139-146.

The aim of the study was to investigate acute toxicity of clove oil for rainbow trout and, using values of haematological and biochemical profiles of blood and histological tissue examinations, to assess the effects of the fish exposure to that anaesthetic. Acute toxicity values of clove oil for

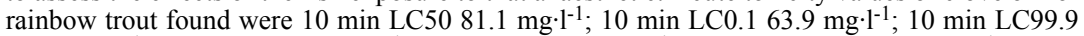
$100.1 \mathrm{mg} \cdot \cdot^{-1} ; 96 \mathrm{~h} \mathrm{LC50} 14.1 \mathrm{mg} \cdot \mathrm{l}^{-1} ; 96 \mathrm{~h} \mathrm{LC} 0.112 .5 \mathrm{mg} \cdot \mathrm{l}^{-1}$, and $96 \mathrm{~h} \mathrm{LC} 99.916 .2 \mathrm{mg} \cdot \mathrm{l}^{-1}$.

Clove oil anaesthesia had no effect on the heamatological profile of blood. A significant increase in the concentration of glucose (GLU) and ammonia $\left(\mathrm{NH}_{3}\right)$, and a significant decrease in the aspartate aminotransferase (AST) activity following a $10 \mathrm{~min}$ anaesthesia were found. A significantly decreased AST activity was also found $24 \mathrm{~h}$ after anaesthesia. Clove oil anaesthesia had no effect on other biochemical indices.

Histological examination of the fish following anaesthesia revealed sporadic ectasia in gill lamellae $24 \mathrm{~h}$ after anaesthesia in $20 \%$ of fish. No histopathological changes were demonstrated in other tissues (liver, spleen, cranial and caudal kidneys).

Results of the examinations suggest that the use of clove oil at a concentration of $30 \mathrm{mg} \cdot \mathrm{l}^{-1}$ does not cause irreversible damage in rainbow trout.
\end{abstract}

Acute toxicity, haematological profile, biochemical profile, blood, histology, examination, tissues

Rapid growth of aquaculture in the world and technological advances applied in it make exacting demands on newly introduced chemicals and preparations. Chemicals used in aquaculture are nowadays subject to strict control, particularly with regard to their safety and efficacy (Taylor and Roberts 1999). Anaesthetics are among important and broadly used veterinary medicines.

An modern fish anaesthetics must meet a number of general requirements, e.g. they must be highly soluble in water, have short induction time, be non-toxic for both fish and humans, have a large safety factor, allow an $a d$ lib intensification of anaesthesia with a possibility of spontaneous recovery, and they must leave no residues in fish (B rožová and S vobodová 1986; Brown 1988; Ross and Ross 1999).

Clove oil is used as an anaesthetic before handling or treating fish in breeding, artificial propagation, blood sampling or for some other veterinary interventions. The use of an anaesthetic facilitates the handling of too big or too agile fish species (Trzebiatowski et al. 1996; Iw a ma et al. 1997; W a gner et al. 2002). At present, clove oil is used in the Czech Republic for short-term immobilization of fish before artificial spawning and whenever fish is handled outside water. The recommended concentration for anaesthetic purposes is 30 $\mathrm{mg} \cdot \mathrm{l}^{-1}$ water bath (Svoboda and Kolářová 1999; Hamáčková et al. 2001).

Clove oil is a dark-brown liquid, a distillate of flowers, stalks and leaves of the clove tree

\footnotetext{
Address for correspondence:

Ing. Josef Velíšek

University of South Bohemia, Faculty of Agriculture

Department of Anatomy and Physiology of Farm Animals

Studentská 13

37005 České Budějovice, Czech Republic
}

\author{
Phone: + 420387772611 \\ Fax: + 420387772621 \\ E-mail: velisek.j@centrum.cz \\ http://www.vfu.cz/acta-vet/actavet.htm
}


Eugenia aromatica (Sato and Burhanuddin 1995). According to Isaacs (1983), Briozza et al. (1989) and Keene et al. (1998), clove oil is distilled from stems, leaves and flower buds of Eugenia caryophyllata, and its active ingredient, i.e. eugenol (4-allyl-2methoxyphenol), makes up 70 to $90 \%$ by weight of clove oil. Clove oil also contains eugenol acetate $(>17 \%)$ and kariofilen $5(>12 \%)$.

In fish, anaesthetics are absorbed and excreted mainly through gills (Locke 1969; Hunn and Allen 1974; Houston and Woods 1976; Ferreira et al. 1984). Eugenol and its compounds and metabolites are quickly removed from the blood bed and tissues of fish (Fisher et al. 1990), and the presence of these substances in muscle tissues of fish or other animals is not considered toxic or mutagenous (Liu and Gibs on 1977; Maura et al. 1989; Fisher et al. 1990; Philips 1990; Zheng et al. 1992).

Clove oil has been used as a mild anaesthetic in humane medicine since antiquity (Nagababu and Lakshmaiah 1992; Ross and Ross 1999; Taylor and Roberts 1999). Eugenol inhibits the synthesis of prostaglandin H (PHS), which accounts for the analgesic effect of clove oil (Dewhirst and Goodson 1974; Thomson and Eling 1989; Pong prayoon et al. 1991).

The aim of the present study was to investigate acute toxicity of clove oil in rainbow trout and, on the basis of haematological indices, biochemical blood profile values and histological examinations, to assess the changes in the organism of rainbow trout induced by the anaesthetic.

\section{Materials and Methods}

In the study, clove oil marketed by the Kulich Company (Jan Kulich, Hradec Králové/Říčany, CR) in $10 \mathrm{ml}$ and $50 \mathrm{ml}$ containers was used.

Acute toxicity of clove oil

Acute toxicity of clove oil was ascertained by the OECD 203 „Fish, acute toxicity test“. For the $96 \mathrm{~h}$ and $10 \mathrm{~min}$ LC50 trials, rainbow trout (kamloops) of $40 \pm 10 \mathrm{~g}$ (mean \pm SD) average weight and $150 \pm 20$ mm average body length were used.

The 96-h LC50 test: Experimental fish were exposed to concentrations 7, 10, 12, 14, 16, 18 and $20 \mathrm{mg} \cdot \mathrm{l}^{-1} \mathrm{clove}$ oil dissolved in diluting water $\left(\mathrm{pH} 7.51\right.$; acid neutralization capacity - $\mathrm{ANA}_{4.5} 1.29 \mathrm{mmol} \cdot \mathrm{l}^{-1}$; total ammonia 0.03 $\mathrm{mg} \cdot \mathrm{l}^{-1} ; \mathrm{NO}_{3}{ }^{-} 7.45 \mathrm{mg} \cdot \mathrm{l}^{-1} ; \mathrm{NO}_{2}^{-} 0.003 \mathrm{mg} \cdot \mathrm{l}^{-1} ; \mathrm{PO}_{4}{ }^{3-} 0.02 \mathrm{mg} \cdot \mathrm{l}^{-1}$; chemical oxygen demand $\left.-\mathrm{COD}_{\mathrm{Mn}} 1.5 \mathrm{mg} \cdot \mathrm{l}^{-1}\right)$, and controls were placed in diluting water with no tested substance added. Ten rainbow trout were used for each concentration and for the control group. The fish and its behaviour, water temperature, $\mathrm{pH}$ and oxygen saturation were monitored throughout the tests at individual concentrations and in the control aquarium. Mean lethal concentration ( $96 \mathrm{~h} \mathrm{LC50)}$ and also $96 \mathrm{~h} \mathrm{LC0.1}$ and $96 \mathrm{~h} \mathrm{LC} 99.9$ were calculated from mortality rates over the period of 96 hours.

The 10-min LC50 test: For $10 \mathrm{~min}$, the fish were exposed to concentrations of 50, 60, 70, 80, 90 and $100 \mathrm{mg} \cdot 1^{-1}$ of clove oil dissolved in diluting water. Ten rainbow trout were used for each concentration and for the control group. Diluting water of the same parameters as in previous trials was used. During the 10 -min test period, changes in physiological parameters of fish and fish mortality figures were recorded, and after the trout had been moved to clean water, the time of their recovery from anaesthesia was determined. Mean lethal concentrations (10 min LC50) and also $10 \mathrm{~min}$ LC0.1 and $10 \mathrm{~min}$ C 99.9 were calculated from mortality rates over the period of $10 \mathrm{~min}$.

In the tests, the onsets of individual phases of anaesthesia and recovery rates were studied. Evaluations were made in four consecutive phases (Thienpoint and Niemegeers 1965; Yoshikawa et al. 1988).

1. acceleration and subsequent deceleration of opercular movements, a partial loss of reactivity to external stimuli

2. loss of equilibrium, opercular movements very slow, fish still reactive to strong stimuli

3. total loss of reactivity, fish are lying at the tank bottom and do not respond to handling

4. complete cessation of opercular movements, fish die if left in the bath for too long.

Lethal concentration levels (LC50, LC0.1 and LC99.9) were determined by the probit analysis using EKO-TOX 5.1 software.

Haematological blood profile after exposure to clove oil

For the haematological blood profile tests, rainbow trout (kamloops) of $102.5 \pm 20 \mathrm{~g}$ (mean $\pm \mathrm{SD}$ ) average weight and $200 \pm 40 \mathrm{~mm}$ average body length were used. A total of 40 fish divided into four groups were examined: Control I (before the anaesthetic administration), Experiment I (immediately after $10 \mathrm{~min}$ anaesthesia at the concentration of $30 \mathrm{mg} \cdot \mathrm{l}^{-1}$ ), Experiment II ( $24 \mathrm{hrs}$ after $10 \mathrm{~min}$ anaesthesia) and Control II (controls examined in parallel with Experiment II). The fish were anesthetized for $10 \mathrm{~min}$ by clove oil at a concentration of $30 \mathrm{mg} \cdot \mathrm{l}^{-1}$. Heparinized injection needles were used to 
take samples of blood from hearts of fish stunned by a blow with a blunt object over the head. To stabilize blood samples, aqueous solution of heparin sodium salt at $0.01 \mathrm{ml}$ per $1 \mathrm{ml}$ blood was used (Sv ob od ová et al. 1991).

The indices used to evaluate the haematological profile included the erythrocyte count (Er), haemoglobin concentration $(\mathrm{Hb})$, haematocrit $(\mathrm{PCV})$, mean erythrocyte volume (MCV), mean colour concentration (MCHC), erythrocyte haemoglobin $(\mathrm{MCH})$, leukocyte count (Leuko) and the differential leukocyte count (Leukogram). The procedures were based on Unified methods for haematological examination of fish (Svobodová et al. 1991).

Results of haematological examinations were tested by the variance analysis using the Statgraphics (ANOVA Tukey Test) software.

Biochemical blood plasma profile after exposure to clove oil

For biochemical profile of blood plasma tests, rainbow trout (kamloops) of $123 \pm 20 \mathrm{~g}$ (mean $\pm \mathrm{SD}$ ) average weight and $230 \pm 40 \mathrm{~cm}$ average body length were used.

Blood plasma was obtained by centrifuging blood samples in a cooled centrifuge $\left(4{ }^{\circ} \mathrm{C}, 837 \mathrm{x} \mathrm{g}\right)$. Biochemical indices determined in blood plasma included glucose (GLU), total protein (TP), albumins (ALB), total globulins (GLOB), ammonia $\left(\mathrm{NH}_{3}\right)$, triacylglycerols (TAG), aspartate aminotransferase (AST), alanin aminotransferase (ALT), lactate dehydrogenase (LDH), creatinkinase (CK), calcium $\left(\mathrm{Ca}^{2+}\right)$ and inorganic phosphate (PHOS). For the biochemical analysis of blood plasma, the VETTEST 8008 analyzer (IDEXX Laboratories Inc. U.S.A.) manufactured by Medisoft was used. The analyzer uses dry chemical and colorimetric analysis techniques. Selective test discs (Multi-layer film slides, Kodak) are used for the evaluation by a laser reading bar codes.

Results of biochemical examination were tested by the variance analysis using the Statgraphics (ANOVA Tukey Test) software.

Histological examination of tissues

For histological examination of tissues, rainbow trout (kamloops) of $123 \pm 20 \mathrm{~g}$ (mean $\pm \mathrm{SD}$ ) average weight and $230 \pm 40 \mathrm{~cm}$ average body length were used.

After blood sampling, samples of gills, liver, cranial and caudal kidneys and spleen were taken for histological examinations. The samples taken were immediately fixed in $10 \%$ formaldehyde, drained and embedded in paraffin. Sections were made of the paraffin blocks and stained with haematoxylin-eosin.

\section{Results}

Acute toxicity of clove oil

During the 96-hour LC50 tests, the mean water temperature was $13.7-15^{\circ} \mathrm{C}$, $\mathrm{pH}$ was $7.41-7.86$ and water oxygen levels were $76-96 \%$ saturation. On the basis of tests of acute toxicity to rainbow trout, the 96-hour lethal concentrations of clove oil were determined (96 h LC50 $14.1 \mathrm{mg} \cdot l^{-1}, 96 \mathrm{~h} \mathrm{LC0.1} 12.5 \mathrm{mg} \cdot \mathrm{l}^{-1}$ and $96 \mathrm{~h} \mathrm{LC} 99.916 .2 \mathrm{mg} \cdot \mathrm{l}^{-1}$ ).

The autopsy performed after the acute toxicity test revealed increased amounts of watery mucous on body surfaces, and the gills were matt dark in colour. The body cavity contained excess moisture, and an increased injection of visceral vessels was also obtained.

During 10-min LC50 tests, water temperature was $14{ }^{\circ} \mathrm{C}$, $\mathrm{pH}$ was 7.76 and water oxygen level was at $98 \%$ saturation. On the basis of tests of acute toxicity to rainbow trout, the 10 -min lethal concentrations of clove oil were determined ( $10 \mathrm{~min}$ LC50 $81.1 \mathrm{mg} \cdot \mathrm{l}^{-1}, 10 \mathrm{~min}$ LC0.1 $63.9 \mathrm{mg} \cdot \mathrm{l}^{-1}$ and $10 \mathrm{~min} \mathrm{LC99.9} 100.1 \mathrm{mg} \cdot \mathrm{l}^{-1}$ ).

Effects of clove oil concentrations on the time of onset of anaesthesia, duration of its individual stages and the course of recovery are shown in Fig. 1.

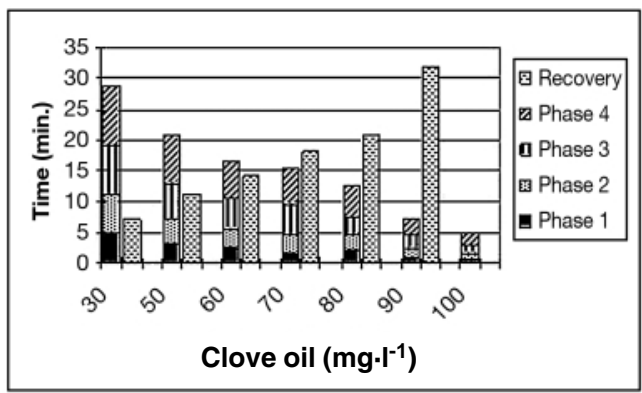

Fig. 1. Effects of clove oil concentrations on the onset of individual phases of anaesthesia and recovery in rainbow trout 
Haematological blood profile after exposure to clove oil

Effects of clove oil on the haematological profile of rainbow trout are showed in Tables 1 and 2 . The 10-min exposure to the anaesthetic at a concentration of $30 \mathrm{mg} \cdot \mathrm{l}^{-1}$ had no effect on the haematological indices studied (Er, Hb, PCV, MCV, MCHC, MCH, Leuko and Leukogram).

Table 1. Effects of clove oil anaesthesia on haematological indices in rainbow trout

\begin{tabular}{|l|c|c|c|c|}
\hline \multicolumn{1}{|c|}{ Indices } & $\begin{array}{c}\text { Control I } \\
\text { (before anaesthesia) } \\
\mathrm{x} \pm \mathrm{SD}(\mathrm{n}=10)\end{array}$ & $\begin{array}{c}\text { Experimental I } \\
\text { (immediately after } \\
\text { anaesthesia) } \\
\mathrm{x} \pm \mathrm{SD}(\mathrm{n}=10)\end{array}$ & $\begin{array}{c}\text { Experimenatal II } \\
(24 \text { hrs after } \\
\text { anaesthesia) } \\
\mathrm{x} \pm \mathrm{SD}(\mathrm{n}=10)\end{array}$ & $\begin{array}{c}\text { Control II } \\
(\text { after 24hrs }) \\
\mathrm{x} \pm \mathrm{SD}(\mathrm{n}=10)\end{array}$ \\
\hline $\mathrm{Er}\left(\mathrm{T} \cdot \mathrm{l}^{-1}\right)$ & $1.43 \pm 0.23^{\mathrm{a}}$ & $1.28 \pm 0.26^{\mathrm{a}}$ & $1.16 \pm 0.25^{\mathrm{a}}$ & $1.06 \pm 0.25^{\mathrm{a}}$ \\
\hline $\mathrm{Hb}\left(\mathrm{g} \cdot \mathrm{l}^{-1}\right)$ & $61.32 \pm 10.08^{\mathrm{a}}$ & $61.99 \pm 12.73^{\mathrm{a}}$ & $58.42 \pm 10.66^{\mathrm{a}}$ & $55.91 \pm 6.84^{\mathrm{a}}$ \\
\hline $\mathrm{PCV}\left(\mathrm{l} \cdot \cdot^{-1}\right)$ & $0.43 \pm 0.05^{\mathrm{a}}$ & $0.44 \pm 0.07^{\mathrm{a}}$ & $0.39 \pm 0.01^{\mathrm{a}}$ & $0.39 \pm 0.03^{\mathrm{a}}$ \\
\hline $\mathrm{MCV}(\mathrm{fl})$ & $305.68 \pm 51.24^{\mathrm{a}}$ & $344.05 \pm 57.67^{\mathrm{a}}$ & $339.79 \pm 56.96^{\mathrm{a}}$ & $378.09 \pm 90.91^{\mathrm{a}}$ \\
\hline $\mathrm{MCH}(\mathrm{pg})$ & $43.67 \pm 9.65^{\mathrm{a}}$ & $49.15 \pm 11.55^{\mathrm{a}}$ & $51.06 \pm 9.75^{\mathrm{a}}$ & $52.44 \pm 10.80^{\mathrm{a}}$ \\
\hline $\mathrm{MCHC}\left(\mathrm{g} \cdot \mathrm{l}^{-1}\right)$ & $141.99 \pm 13.32^{\mathrm{a}}$ & $141.71 \pm 10.79^{\mathrm{a}}$ & $150.46 \pm 15.87^{\mathrm{a}}$ & $140.19 \pm 14.41^{\mathrm{a}}$ \\
\hline Leuko $\left(\mathrm{G} \cdot \mathrm{l}^{-1}\right)$ & $23.70 \pm 11.31^{\mathrm{a}}$ & $23.70 \pm 4.69^{\mathrm{a}}$ & $19.60 \pm 9.96^{\mathrm{a}}$ & $17.6 \pm 6.42^{\mathrm{a}}$ \\
\hline
\end{tabular}

Groups with different alphabetic superscripts differ significantly at $\mathrm{p}<0.05$ (ANOVA)

Table 2. Effects of clove oil anaesthesia on differential leukocyte counts in rainbow trout

\begin{tabular}{|c|c|c|c|c|c|}
\hline Indices & & $\begin{array}{c}\text { Control I } \\
\text { (before anaesthesia) } \\
\mathrm{x} \pm \mathrm{SD}(\mathrm{n}=10)\end{array}$ & $\begin{array}{l}\text { Experimental I } \\
\text { (immediately after } \\
\text { anaesthesia) } \\
\mathrm{x} \pm \mathrm{SD}(\mathrm{n}=10)\end{array}$ & $\begin{array}{l}\text { Experimental II } \\
(24 \mathrm{hrs} \text { after } \\
\text { anaesthesia }) \\
\mathrm{x} \pm \mathrm{SD}(\mathrm{n}=10)\end{array}$ & $\begin{array}{c}\text { Control II } \\
(\text { after } 24 \mathrm{hrs}) \\
\mathrm{x} \pm \mathrm{SD}(\mathrm{n}=10)\end{array}$ \\
\hline \multirow[t]{2}{*}{ Lymphocytes } & $\%$ & $74.30 \pm 15^{\mathrm{a}}$ & $74.70 \pm 13^{\mathrm{a}}$ & $78.70 \pm 9.40^{\mathrm{a}}$ & $78.30 \pm 11^{\mathrm{a}}$ \\
\hline & $g \cdot l^{-1}$ & $18.02 \pm 9.49^{\mathrm{a}}$ & $19.01 \pm 5.26^{\mathrm{a}}$ & $13.77 \pm 4.55^{\mathrm{a}}$ & $15.73 \pm 8.77^{\mathrm{a}}$ \\
\hline \multirow[t]{2}{*}{ Monocytes } & $\%$ & $2.20 \pm 2.20^{\mathrm{a}}$ & $2.80 \pm 3.40^{\mathrm{a}}$ & $1.60 \pm 1.70^{\mathrm{a}}$ & $3.20 \pm 2.30^{\mathrm{a}}$ \\
\hline & $g \cdot 1^{-1}$ & $0.47 \pm 0.35^{\mathrm{a}}$ & $0.71 \pm 0.91^{\mathrm{a}}$ & $0.34 \pm 0.49^{\mathrm{a}}$ & $0.58 \pm 0.46^{\mathrm{a}}$ \\
\hline \multirow{2}{*}{$\begin{array}{l}\text { Neutrophile } \\
\text { granulocytes } \\
\text { segment }\end{array}$} & $\%$ & $18.7 \pm 15^{\mathrm{a}}$ & $13.6 \pm 9.60^{\mathrm{a}}$ & $14 \pm 8.0^{\mathrm{a}}$ & $12 \pm 9.50^{a}$ \\
\hline & $g \cdot l^{-1}$ & $4.16 \pm 2.91^{\mathrm{a}}$ & $3.04 \pm 1.86^{\mathrm{a}}$ & $2.51 \pm 1.74^{\mathrm{a}}$ & $3.55 \pm 4.29^{a}$ \\
\hline \multirow{2}{*}{$\begin{array}{l}\text { Neutrophile } \\
\text { granulocytes } \\
\text { rods }\end{array}$} & $\%$ & $0.20 \pm 0.42^{\mathrm{a}}$ & $0.10 \pm 0.32^{\mathrm{a}}$ & $0.10 \pm 0.32^{a}$ & $0.30 \pm 0.48^{a}$ \\
\hline & $g \cdot 1^{-1}$ & $0.05 \pm 0.10^{\mathrm{a}}$ & $0.03 \pm 0.05^{\mathrm{a}}$ & $0.02 \pm 0.01^{\mathrm{a}}$ & $0.05 \pm 0.07^{\mathrm{a}}$ \\
\hline \multirow{2}{*}{$\begin{array}{l}\text { Developmental } \\
\text { phases-myeloid } \\
\text { sequence }\end{array}$} & $\%$ & $4.60 \pm 2.07^{\mathrm{a}}$ & $3.80 \pm 4.20^{\mathrm{a}}$ & $6.20 \pm 2.87^{\mathrm{a}}$ & $5.60 \pm 3.24^{\mathrm{a}}$ \\
\hline & $g \cdot l^{-1}$ & $0.92 \pm 0.76^{\mathrm{a}}$ & $1.11 \pm 0.68^{a}$ & $1.16 \pm 0.92^{\mathrm{a}}$ & $1.15 \pm 0.52^{a}$ \\
\hline
\end{tabular}

Groups with different alphabetic superscripts differ significantly at $\mathrm{p}<0.05$ (ANOVA)

Biochemical blood plasma profile after exposure to clove oil

Effects of clove oil on the blood plasma biochemical profile of rainbow trout are given in Tab. 3. The 10-min exposure to clove oil at a concentration of $30 \mathrm{mg} \cdot \mathrm{l}^{-1}$ caused a significant $(p<0.05)$ increase in the concentration of glucose and ammonia immediately after anaesthesia. Their values returned back to normal within 24 hours. AST levels were down compared with control groups immediately and 24 hours after anaesthesia $(p<0.05)$. The rest of the indices (TP, ALB, GLOB, TAG, ALT, LDH, CK, $\mathrm{Ca}^{2+}$ and PHOS) were at comparable levels in all groups. 
Table 3. Effects of clove oil anaesthesia on biochemical indices of blood plasma in rainbow trout

\begin{tabular}{|c|c|c|c|c|}
\hline Indices & $\begin{array}{c}\text { Control I } \\
\text { (before anaesthesia) } \\
\mathrm{x} \pm \mathrm{SD}(\mathrm{n}=10)\end{array}$ & $\begin{array}{c}\text { Experimental I } \\
\text { (immediately after } \\
\text { anaesthesia) } \\
\mathrm{x} \pm \mathrm{SD}(\mathrm{n}=10)\end{array}$ & $\begin{array}{l}\text { Experimental II } \\
(24 \text { hrs after } \\
\text { anaesthesia }) \\
\mathrm{x} \pm \mathrm{SD}(\mathrm{n}=10)\end{array}$ & $\begin{array}{c}\text { Control II } \\
\text { (after } 24 \mathrm{hrs}) \\
\mathrm{x} \pm \mathrm{SD}(\mathrm{n}=10)\end{array}$ \\
\hline $\operatorname{GLU}\left(\mathrm{mmol} \cdot 1^{-1}\right)$ & $5.59 \pm 1.36^{\mathrm{a}}$ & $8.87 \pm 1.41^{\mathrm{b}}$ & $5.96 \pm 1.02^{\mathrm{a}}$ & $5.84 \pm 0.85^{\mathrm{a}}$ \\
\hline $\mathrm{TP}\left(\mathrm{g} \cdot \mathrm{l}^{-1}\right)$ & $37 \pm 7.02^{a}$ & $37.7 \pm 24.30^{a}$ & $38.0 \pm 11.20^{\mathrm{a}}$ & $36.3 \pm 2.66^{\mathrm{a}}$ \\
\hline $\operatorname{ALB}\left(g \cdot 1^{-1}\right)$ & $8.7 \pm 1.11^{\mathrm{a}}$ & $8.6 \pm 1.96^{\mathrm{a}}$ & $9.0 \pm 1.87^{\mathrm{a}}$ & $8.6 \pm 2.87^{a}$ \\
\hline $\operatorname{GLOB}\left(g \cdot 1^{-1}\right)$ & $28.5 \pm 4.52^{a}$ & $29.1 \pm 1.66^{\mathrm{a}}$ & $29.0 \pm 2.61^{\mathrm{a}}$ & $28 \pm 1.66^{\mathrm{a}}$ \\
\hline $\mathrm{NH}_{3}\left(\mu \mathrm{mol} \cdot l^{-1}\right)$ & $264 \pm 47^{\mathrm{a}}$ & $403 \pm 72^{b}$ & $263 \pm 38^{a}$ & $266 \pm 31^{a}$ \\
\hline TAG $\left(\mathrm{mmol} \cdot \mathrm{l}^{-1}\right)$ & $1.07 \pm 0.31^{\mathrm{a}}$ & $1.07 \pm 0.11^{\mathrm{a}}$ & $1.08 \pm 0.26^{\mathrm{a}}$ & $1.03 \pm 0.32^{\mathrm{a}}$ \\
\hline $\operatorname{AST}\left(\mu \mathrm{kat} \cdot \mathrm{l}^{-1}\right)$ & $3.69 \pm 2.09^{\mathrm{a}}$ & $2.12 \pm 2.08^{b}$ & $2.09 \pm 1.09^{b}$ & $3.79 \pm 0.44^{\mathrm{a}}$ \\
\hline $\operatorname{ALT}\left(\mu \mathrm{kat} \cdot \mathrm{l}^{-1}\right)$ & $0.18 \pm 0.06^{\mathrm{a}}$ & $0.18 \pm 0.07^{\mathrm{a}}$ & $0.17 \pm 0.05^{\mathrm{a}}$ & $0.19 \pm 0,04^{\mathrm{a}}$ \\
\hline LDH $\left(\mu \mathrm{kat} \cdot \mathrm{l}^{-1}\right)$ & $18.2 \pm 1.09^{\mathrm{a}}$ & $18.5 \pm 1.02^{\mathrm{a}}$ & $18.0 \pm 1.25^{\mathrm{a}}$ & $18.3 \pm 0.92^{\mathrm{a}}$ \\
\hline $\mathrm{CK}\left(\mu \mathrm{kat} \cdot \cdot^{-1}\right)$ & $13.1 \pm 2.05^{\mathrm{a}}$ & $12.8 \pm 1.23^{\mathrm{a}}$ & $13.4 \pm 3.25^{\mathrm{a}}$ & $13.0 \pm 1.65^{\mathrm{a}}$ \\
\hline $\mathrm{Ca}^{2+}\left(\mathrm{mmol} \cdot \mathrm{l}^{-1}\right)$ & $2.89 \pm 0.23^{a}$ & $2.91 \pm 0.09^{\mathrm{a}}$ & $2.87 \pm 0.13^{\mathrm{a}}$ & $2.89 \pm 0.18^{a}$ \\
\hline PHOS $\left(\mathrm{mmol} \cdot \mathrm{l}^{-1}\right)$ & $3.32 \pm 0.23^{\mathrm{a}}$ & $3.40 \pm 0.17^{\mathrm{a}}$ & $3.41 \pm 0.28^{\mathrm{a}}$ & $3.35 \pm 0.36^{\mathrm{a}}$ \\
\hline
\end{tabular}

Groups with different alphabetic superscripts differ significantly at $\mathrm{p}<0.05$ (ANOVA)

\section{Histological examination of tissues}

All rainbow trout showed capillary ectasia of gill filaments immediately after clove oil anaesthesia. Twenty-four hours after anaesthesia, sporadic ectasia was only demonstrated at the ends of gill lamellae in $20 \%$ of the fish. No histopathological changes were demonstrated in other tissues (liver, spleen, cranial and caudal kidneys) following anaesthesia.

\section{Discussion}

Acute toxicity of clove oil to fish is investigated from the point of view of clove oil use as an anaesthetic, and of risk of water contamination with anaesthetizing baths. The $10 \mathrm{~min}$ LC50 (LC0.1; LC99.9) values characterize clove oil toxicity in the case of a 10 min exposure to the anaesthetic. Taylor and Roberts (1999) determined 10 min LC50 of clove oil to Oncorhynchus tchawytcha and rainbow trout (Oncorhynchus mykiss) at $62 \mathrm{mg} \cdot \mathrm{l}^{-1}$ and 250 $\mathrm{mg} \cdot \mathrm{l}^{-1}$, respectively. The $10 \mathrm{~min}$ LC50 of clove oil found in the present study of rainbow trout $\left(81.1 \mathrm{mg} \cdot \mathrm{l}^{-1}\right)$ is comparable with the figure reported for Oncorhynchus tchawytcha, and it is about three time lower than the figure reported for rainbow trout.

To assess the anaesthetic from the point of view of water contamination risks, $96 \mathrm{~h} \mathrm{LC50}$ values are used. In their study of juvenile rainbow trout, Keene et al. (1998) reported LC50 for the 8 to $96 \mathrm{~h}$ period at approximately $9 \mathrm{ppm}\left(10 \mathrm{mg} \cdot \mathrm{l}^{-1}\right)$. That value is in good agreement with $96 \mathrm{~h} \mathrm{LC50}$ of $14.1 \mathrm{mg} \cdot \mathrm{l}^{-1}$ for rainbow trout fry found in the present study.

The generally reported clove oil concentration as a fish anaesthetic is $30 \mathrm{mg} \cdot \mathrm{l}^{-1}$ ( $\mathrm{Sv}$ o b o da and Kolářová 1999). Prince and Powell (2000) also recommended the concentration of $30 \mathrm{mg} \cdot \mathrm{l}^{-1}$ clove oil for effective and safe anaesthesia of adult rainbow trout. Drawing on the results of their study into clove oil effects on rainbow trout, Keene et al. (1998) concluded that clove oil was a suitable anaesthetic for aquaculture purposes. The concentrations used (40-60 ppm) successfully induced anaesthesia in juvenile rainbow trout with a relatively short recovery period. Griffiths (2000) recommended a concentration of $40 \mathrm{mg} \cdot \mathrm{l}^{-1}$ clove oil for rainbow trout anaesthesia. At that concentration, anaesthesia is induced in $4 \mathrm{~min}$ and the fish will recover in $14 \mathrm{~min}$. Soto and Burhanuddin (1995) and Anderson et al. (1997) used clove oil at concentrations 33-120 mg $\cdot 1^{-1}$ in their studies with Siganus lineatus and rainbow trout. At the concentration of $33 \mathrm{mg} \cdot \mathrm{l}^{-1}$, rainbow trout lost equilibrium in 150 sec and were totally immobilized within $190 \mathrm{~s}$. 
To evaluate haematological and biochemical profiles of blood and histopathological changes in tissues of rainbow trout, clove oil concentration of $30 \mathrm{mg} \cdot \mathrm{l}^{-1}$ was used in the present study. Haematological and biochemical profiles of blood can provide important information about the internal environment of the organism (Masopust 2000). Values determined in the present study suggest that internal organs and tissues of rainbow trout are not altered by clove oil anaesthesia. That conclusion was also confirmed by the result of histological examination of parenchymatous organs.

In their study of anaesthetized Atlantic salmon (Salmo salar), Iverzen et al. (2003) found no change in the concentration of glucose and increased concentrations of lactate and cortisol following clove oil anaesthesia. An increase in cortisol levels related to clove oil anaesthesia has also been reported by Wagner et al. (2002) in rainbow trout. On the other hand, Hollow ay et al. (2004) found decrease of cortisol concentration in rainbow trout. In our experiments with rainbow trout, a significant increase $(p<0.05)$ in blood plasma glucose and ammonia immediately after the 10-min clove oil anaesthesia was observed. Increased glucose and ammonia levels returned to normal 24 hours after anaesthesia. These findings are in keeping with results of Hollow ay et al. (2004) who also detected increase of glucose concentration following clove oil anaesthesia.

Clove oil meets seven out of eight criteria for an ideal anaesthetic (Marking and Meyer 1985). Its main advantage is its low price. The use of clove oil, however, requires that general principles of safe handling of chemicals be observed. The authors know from their own experience that a stay in a poorly ventilated room where clove oil is used may cause headache, nausea and fatigue in vulnerable persons. The disadvantage of clove oil is its relatively low therapeutic index, i.e. the ratio between the therapeutic and the toxic concentrations. The generally reported optimum ratio is 1:4 or higher (Svobodová and Vykusová 1991). A comparison between the concentration used in a 10 -min anaesthesia of fish $\left(30 \mathrm{mg} \cdot \mathrm{l}^{-1}\right)$ and the $10 \mathrm{~min}$ LC50 values found $\left(81.1 \mathrm{mg}^{-1} \mathrm{l}^{-1}\right)$ suggests that the clove oil therapeutic index is 1:2.7.

\section{Vliv anestetika hřebíčkového oleje na pstruha duhového (Oncorhynchus mykiss)}

Cílem práce bylo posoudit akutní toxicitu hřebíčkového oleje pro pstruha duhového a pomocí hodnot hematologického vyšetření, biochemického profilu krve a histologického vyšetření tkání posoudit stav tkání pstruhů duhových po působení tohoto anestetika. Akutní toxicita hřebíčkového oleje pro pstruha duhového byla následující: $10 \mathrm{~min}$ LC50 $81.1 \mathrm{mg} \cdot \mathrm{l}^{-1} ; 10 \mathrm{~min}$ LC0.1 $63.9 \mathrm{mg} \cdot \mathrm{l}^{-1} ; 10 \mathrm{~min} \mathrm{LC99.9} 100.1 \mathrm{mg} \cdot \mathrm{l}^{-1} ; 96 \mathrm{~h} \mathrm{LC50} 14.1 \mathrm{mg} \cdot \mathrm{l}^{-1} ; 96 \mathrm{~h} \mathrm{LC0.1} 12.5 \mathrm{mg} \cdot \mathrm{l}^{-}$ 1; 96 h LC99.9 $16.2 \mathrm{mg} \cdot \mathrm{l}^{-1}$. Hřebíčkový olej neovlivnil hematologický profil krve pstruha duhového. Po 10 min anestézie hřebíčkovým olejem bylo zaznamenáno významné zvýšení $(\mathrm{p}<$ $0.05)$ koncentrace glukózy (GLU) a amoniaku $\left(\mathrm{NH}_{3}\right)$ a významné snížení $(\mathrm{p}<0.05)$ aktivity aspartátaminotransferázy (AST). Ta byla významně snížena i za 24 hodin po anestézii.

Histologické vyšetření ryb po anestézii prokázalo výskyt ektázií na žaberních lístečcích, 24 hodin po anestézii byly ektázie prokázány ojediněle u $20 \%$ kusů. V ostatních tkáních (játra, slezina, kraniální a kaudální ledvina) nebyly zjištěny histopatologické změny.

Výsledky ukázaly, že hřebíčkový olej $\mathrm{v}$ koncentraci $30 \mathrm{mg} \cdot \mathrm{l}^{-1}$ se jeví pro pstruha duhového bezpečný.

\section{Acknowledgements}

The present study was conducted as part of the Ministry of Agriculture Project NAZV QF3029 Harmonization with the EU in applying pharmacovigilance principles in aquaculture in the Czech Republic, and the GACR 523/03/H076 Project.

\section{References}

ANDERSON, WG, MCKINLEY, RS, COLAVECCHIA, M 1997: The use of clove oil as an anaesthetic for rainbow trout and its effects on swimming performance. N Amer J Fish Manage 17: 301-307 
BRIOZZO, JL, CHIRIFE, J, HERZAGE, L, D'AQUINO, M 1989: Antimicrobial activity of clove oil dispersed in a concentrated sugar solution. J Appl Bacteriol 66: 69-75

BROŽOVÁ, V, SVOBODOVÁ, Z 1986: Anaesthetics for fish. Bull VÚRH Vodňany (In Czech) 20:36-40

BROWN, LA 1988: Tropical fish medicine. Anesthesia in fish. Vet Clin N Amer-Small Anim 18:317-330

DEWHIRST, FE, GOODSON, JM 1974: Prostaglandin synthetase inhibition by eugenol, guaiacol and other dental medicaments. J Dent Res 53: 104-105

FERREIRA, JT, SMITH, GL, SCHOONBEE, HJ 1984: The effect of the anaesthetic benzocaine-hydrochloride on freshwater quality. Water Sa 5: 123-127

FISHER, IU, VON UHRUH, GH, DENGER, HJ 1990: The metabolism of eugenol in man. Xenobiotica 20: 209-222

GRIFFITHS, SP 2000: The use of clove oil as an anaesthetic and method for sampling intertidal rockpool fishes. J Fish Biol 57: 1453-1464

HAMÁČKOVÁ, J, SEDOVÁ, JM, PJANOVÁ, SV, LEPIČOVÁ, A 2001: The effect 2-phenoxyethanol, clove oil and Propiscin anaesthetics on perch (Perca fluviatilis) in relation to water temperature. Czech J Anim Sci 46: 469-473

HOLLOWAY, AC, KEENE, J, NOAKES, DG, MOCCIA, RD 2004: Effects of clove oil and MS-222 on blood hormone profiles in rainbow trout Oncorhynchus mykiss, Walbaum. Aquac Res 35: 1025-1030

HOUSTON, AH, WOODS, JR 1976: Influence of temperature upon tricaine methane sulphonate uptake and induction of anaesthesia in rainbow trout, Salmo gairdneri. Comp Biochem Physiol 54: 1-6

HUNN, JB, ALLEN, J 1974: Movement of drugs across the gills of fishes. Ann Rev Pharmacol Toxicol 14: 47-55

ISAACS, G 1983: Permanent local anaesthesia and anhidrosis after clove oil spillage. Lancet 1: 882-883

IVERZEN, M, FINSTAD, B, MCKINLEY, RS, ELIASSEN, RA 2003: The efficasy of metomidate, clove oil, Agui-S and Benzoak as anaesthetics in Atlantic salmon stress - reducing capacity. Aquaculture 221: 549-566

IWAMA, GK, PICKERING, AD, SUMPTER, JP, SCHRECK, CB 1997: Fish stress and health in aquaculture. Cambridge Univ Press UK 278 p.

KEENE, JL, NOAKES, DLG, MOCCIA, RD, SOTO, CG. 1998: The efficacy of clove oil as an anaesthetic for rainbow trout, Oncorhynchus mykiss (Walbaum). Aquac Res 29: 89-101

LIU, EH, GIBSON, DM 1977: Visualization of peroxidase isozymes with eugenol, a noncarcinogenic substrate. Anal Biochem 79: 597-601

LOCKE, DO 1969: Quinaldine as an anaesthetic for brook trout, lake trout and Atlantic salmon. US Fish and Wildlife Service, Investigations in Fish Control 24 Washington DC.

MARKING, LL, MEYER, FP 1985: Are better fish anaesthects needed in fisheries? Fisheries 10:2-5

MASOPUST, J 2000: Clinical biochemistry. Karolinum Praha (In Czech) 832 p.

MAURA, A, PINO, A, RICCI, R 1989: Negative evidence in vivo of DNA-damaging, mutagenic and chromosomal effects of eogenol. Mutation Res 227: 125-129

NAGABABU, E, LAKSHMAIAH, N 1992: Inhibitory effects of eugenol on non-enzymatic lipid peroxidation in rat liver mitochondria. Biochemical Pharmacology 43: 2393-2400

PHILLIPS, DH 1990: Further evidence that eugenol does not bind to DNA in vivo. Mutat Res 243: 23-26

PONGPRAYOON, U, BAEKSTROM, P, JACOBSSO, U, LINSTROM, M, BOHLIN, L 1991: Compounds inhibiting prostaglandin synthesis isolated from Ipomoea pes-caprae. Planta Med 57: 515-518

PRINCE, A, POWELL, C 2000: Clove oil as an anaesthetic for invasine field procedures on adult rainbow trout. N Amer Fish Manage 20: 1029-1032

ROSS, LG, ROSS, B 1999: Anaesthetic and sedative techniques for aquatic animals. Institute of Aquaculture, Univ of Stirling 58: 145-155

SATO, CG, BURHANUDDIN, S 1995: Clove oil as a fish anaesthetic for measuring length and weight of rabbitfish (Siganus lineatus). Aquaculture 136: 149-152

SVOBODA, M, KOLÁŔOVÁ, J 1999: A survey of anaesthetics used in the fish farming. Health Protection of Fish - Proceeding of Papers. Research Institute of Fish Culture and Hydrobiology Vodňany (In Czech): 49-72

SVOBODOVÁ, Z, PRAVDA, D, PALÁČKOVÁ, J 1991: Unified methods of haematological examination of fish. Research Institute of Fish Culture and Hydrobiology Vodňany Methods No 20: 31 p.

SVOBODOVÁ, Z, VYKUSOVÁ, B 1991: Diagnostics, prevention and therapy of fish diseases and intoxications. Manual for International Training Course on Fresh-Water Fish Diseases and Intoxications. Research Institute of Fish Culture and Hydrobiology, Vodňany 270 p.

TAYLOR, PW, ROBERTS, SD 1999: Clove oil: An alternative anaesthetic for aquaculture. N Amer J Aquac 61: $150-155$

THEINPOINT, D, NIEMEGEERS, CJE 1965: R 7464- a new potent anaesthetic in fish. International Zoo Yearbook 5: 202-205

THOMPSON, D, ELING, T 1989: Mechanism of inhibition of prostaglandin H synthase by eugenol and other phenolic peroxidase substrates. Mol Pharmacol 36: 809-817

TRZEBIATOWSKI, R, STEPANOWSKA, K, SIWICKI, AK, KAZUN, K 1996: Badania nad przydatnoscia preparatu propiscin do znieczulenia ogólnego suma europejskiego. Komunikaty Rybackie 1: 14-18 
WAGNER, E, ARUDT, R, HILTON, B 2002: Physiological stress responses, egg surival and sperm mobility for rainbow trout broodstock anesthetized with clove oil, tricaine methanesulfonate or carbon dioxide. Aquaculture 211: 353-366

YOSHIKAWA, H, ISHIDA, Y, UENO, S, MITSUDA, H 1988: Changes in depth of anesthesia of the carp anaesthetized with a costant level of carbon dioxide. Bull Jap Soc Sci Fish 54: 457-462

ZHENG, G, KENNEY, PM, LAM, LKT 1992: Sesquiterpenes from clove (Eugenia caryophyllata) as potential anticarcinogenic agens. J Nat Prod 55: 999-1003 